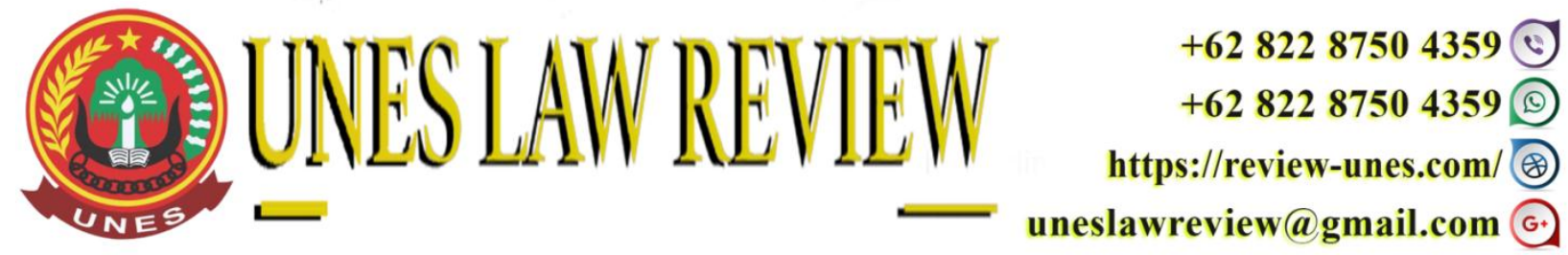

DOI: https://doi.org/10.31933/unesrev.v3i2

Diterima: 11/01/2021, Diperbaiki: 22/01/2021, Diterbitkan: 20/02/2021

\title{
PENERAPAN ILMU KRIMINALISTIK PADA PENYIDIKAN TINDAK PIDANA CABUL DENGAN KORBAN TUNA WICARA
}

\section{Agnes Fajri}

Program Magister Ilmu Hukum, Universitas Ekasakti, Padang, Indonesia

Email: dedekchaniago94@yahoo.com

Corresponding Author: Agnes

\section{ABSTRACT}

The application of criminalism in investigating obscene crimes against speech impaired victims by the PPA Unit of the Satreskrim Polres Agam is a science to help strategies in making light of cases. Criminal science is used to obtain information from victims as crown witnesses or victim witnesses, which is rather difficult to do. This is because the daily conditions of the victim cannot hear (deaf), do not speak (mute), so they cannot communicate properly like normal people, and never go to school. In this regard, investigators use criminalistic science with forensic psychology aids, forensic medicine aids and body language or sign science for the deaf. In forensic medicine, it is used by doing visum et repertum as evidence of violence against the reproductive organs. Forensic Psychology is used to examine the victim's psyche and his honesty about what he is going through. During the investigation into the investigation, the victim was also accompanied by a teacher from the Lubuk Basung Special Elementary School (SDLB). Victims are also examined using props or pictures to make it easier for victims to remember what happened to them, because the victim's memory as a person with a mute disability has limitations.

Kata Kunci: Kriminalistik, Korban, Tindak Pidana Cabul, Tuna Wicara

\section{PENDAHULUAN}

Pasal 1 ayat 3 Undang-Undang Dasar Negara Republik Indonesia. menyatakan bahwa Indonesia adalah negara hukum. Negara hukum menurut Munir Fuady adalah suatu sistem kenegaraan yang diatur berdasarkan hukum yang berlaku yang berkeadilan yang tersusun dalam suatu konstitusi, dimana semua orang dalam negara tersebut, baik yang diperintah maupun yang memerintah harus tunduk pada hukum yang sama, sehingga setiap orang yang sama diperlakukan sama dan setiap orang berbeda diperlakukan berbeda dengan pembedaan yang rasional, tanpa memandang perbedaan warna kulit, ras, gender, agama, daerah, dan kepercayaan dan kewenangan pemerintah dibatasi undang undang. 
Kejahatan merupakan perilaku seseorang yang melanggar hukum positif atau hukum yang telah dilegitimasi berlakunya dalam suatu Negara. Didalam pergaulan masyarakat, setiap hari terjadi hubungan antara anggota - anggota masyarakat yang satu dengan yang lainnya. Pergaulan tersebut menimbulkan berbagai peristiwa atau kejadian yang dapat menggerakkan peristiwa hukum. kejahatan hadir di tengah masyarakat sebagai model perilaku yang sudah dirumuskan secara yuridis sebagai pelanggar dan dilarang oleh hukum dan telah ditetapkan oleh pengadilan yang telah mempunyai kekuatan hukum tetap.

Hukum Pidana merupakan sarana yang penting dalam penanggulangan kejahatan atau mungkin sebagai obat dalam memberantas kejahatan yang meresahkan dan merugikan masyarakat pada umumnya dan korban pada khususnya. Penanggulangan kejahatan tersebut dapat dilakukan secara preventif (pencegahan) dan represif (penindakan). Sesuai dengan sifat sanksi pidana sebagai sanksi terberat atau paling keras dibandingkan dengan jenis-jenis sanksi dalam berbagai bidang hukum yang lain, idealnya fungsionalisasi hukum pidana haruslah ditempatkan sebagai upaya terakhir (ultimum remidium).

Pada proses hukum acara pidana penyidikan merupakan dasar untuk menentukan suatu perbuatan sebagai tindak pidana dan sebagai proses pengumpulan alat bukti yang lengkap. Dalam ketentuan umum Kitab Undang-Undang Hukum Acara Pidana (KUHAP) yaitu Undangundang Nomor 8 tahun 1981, Pasal 1 butir 1 dan 2 merumuskan pengertian penyidikan. Penyidikan tindak pidana pada hakekatnya adalah suatu upaya penegakan hukum yang bersifat pembatasan dan pengekangan hak hak warga negara, bertujuan untuk memulihkan terganggunya keseimbangan antara kepentingan individu dan kepentingan umum agar terpelihara dan terciptanya situasi keamanan dan ketertiban, oleh karena penyidikan tindak pidana juga merupakan bagian dari penegakan hukum pidana, maka harus dilaksanakan berdasarkan ketentuan dan peraturan perundangan yang berlaku.

Pada proses penyidikan penyidik biasanya menggunakan ilmu-ilmu bantu lain guna mengungkap suatu kasus tindak pidana salah satunya adalah ilmu bantu kriminalistik. Ilmu bantu kriminalistik ini juga menggunakan ilmu-ilmu alam untuk menunjang penerapannnya. Kriminalistik adalah ilmu pengetahuan untuk menentukan terjadinya kejahatan dengan menggunakan ilmu bantu lainnya seperti: ilmu kedokteran kehakiman (sekarang ilmu kedokteran forensik), ilmu racun kehakiman (sekarang toksikologi forensik) dan ilmu penyakit jiwa kehakiman (ilmu psikologi forensik).

Salah satu tindak pidana yang terjadi di wilayah hukum Polres Agam adalah tindak pidana pencabulan dan persetubuhan yang dilakukan terhadap korban yang menderita disabilitas. Penyidik kesulitan dalam hal memperoleh keterangan dari korban dikarenakan kondisi korban sebagai seorang disabilitas. Dalam perkara tindak pidana cabul ini, penyidik memerlukan peran ilmu kriminalistik guna mengungkap perkara tersebut.

Berdasarkan latar belakang yang dipaparkan di atas, maka permasalahan yang dibahas adalah penerapan ilmu kriminalistik dalam penyidikan tindak pidana cabul terhadap korban tuna wicara oleh unit PPA Satreskrim Polres Agam. 


\section{METODE PENELITIAN}

Spesifikasi penelitian adalah deskriptif analitis, dengan metode pendekatan yuridis normative didukung oleh yuridis empiris. Jenis data yang digunakan adalah data sekunder. Data sekunder diperoleh dari studi dokumen dan studi kepustakaan. Data yang diperoleh kemudian dianalisa secara kualitatif .

\section{HASIL DAN PEMBAHASAN}

\section{Penerapan Ilmu Kriminalistik Dalam Penyidikan Tindak Pidana Cabul Terhadap Korban Tuna Wicara Oleh Unit PPA Satreskrim Polres Agam}

Ilmu bantu kriminalistik ini juga menggunakan ilmu-ilmu alam untuk menunjang penerapannnya. Kriminalistik adalah ilmu pengetahuan untuk menentukan terjadinya kejahatan dengan dengan menggunakan ilmu bantu lainnya seperti: ilmu kedokteran kehakiman (sekarang ilmu kedokteran forensik), ilmu racun kehakiman (sekarang toksikologi forensik) dan ilmu penyakit jiwa kehakiman (ilmu psikologi forensik).

Peran kriminalistik dalam kasus tindak pidana cabul terhadap korban tuna wicara adalah dengan penggunaan ilmu psikologi forensik. Adapun perkara yang terjadi adalah ketika ayah korban pada hari jum'at tanggal 23 November 2018 sekira pukul 10.00 Wib bertempat di rumah korban yaitu anaknya, pada saat itu anaknya yang bernama Sdri.Yuliza Pgl.Liza mengalami sakit perut, kemudian di bawa ke puskesmas, setelah di periksa oleh petugas di puskesmas pada saat itu korban dinyatakan hamil, setelah dari puskesmas pulang ke rumah, sesampai di rumah ayah korban memberi tahu kepada Paman dari korban, kemudian paman korban menanyakan dengan bahasa isyarat, lalu korban mejelaskan dengan bahasa isyarat bahwa yang telah menyetubuhinya adalah orang pasia yang menggunakan motor, kemudian ayah dan paman korban beserta masyarakat membawa korban berkeliling kampung untuk mencari pelaku yang diduga telah menyetubuhi korban, dalam perjalanan korban menunjuk- nunjuk kearah tersangka yang pada saat itu sedang duduk di depan rumahnya, kemudian ayah dan paman korban beserta masyarakat dan korban menghampiri tersangka dan paman korban langsung bertanya kepada tersangka "waang yang mangarajoan nyo?" (kamu yang menyetubuhi korban) dan tersangka menjawab dan mengakui perbuatan nya, sehingga paman dan ayah korban kemudian melaporkan kejadian tersebut ke Polres Agam.

Pada proses penyidikan guna mendapatkan keterangan korban sabagai saksi mahkota atau saksi korban, agak sulit dilakukan. Hal ini dikarenakan kondisi sehari hari korban tidak dapat mendengar (Tuli), tidak berbicara (bisu), sehingga tidak dapat berkomunikasi layak nya seperti orang normal, dan tidak pernah bersekolah. Berkaitan dengan hal tersebut maka penyidik menggunakan ilmu kriminalistik dengan ilmu bantu psikologi forensik dan Bahasa tubuh atau isyarat.

Pada ilmu kedokteran forensik digunakan dengan melakukannya visum et repertum. visum et repertum ini berguna sebagai alat bukti yang sah yang digunakan dalam suatu pemeriksaan penyidikan. Ilmu kedokteran forensik adalah ilmu kedokteran yang diaplikasikan untuk kepentingan peradilan pidana. Dimana ilmu ini mepelajari sebab kematian, identifikasi, 
keadaan mayat postmortem, perlukaan, abortus, dan pembunuhan anak, perzinahan, dan perkosaan, serta pemeriksaan noda darah. visum et repertum adalah keterangan tertulis yang dibuat oleh dokter dalam ilmu kedokteran forensik atas permintaan penyidik yang berwenang mengenai hasil pemeriksaan medik terhadap manusia, baik hidup atau mati ataupun bagian atau diduga bagian tubuh manusia, berdasarkan keilmuannya dan di bawah sumpah, untuk kepentingan pemeriksaan suatu perkara pidana.

Kejahatan yang dilakukan terhadap penyandang disabilitas sebagian besar tidak terlihat, dan dapat diperkirakan bahwa kejahatan terhadap penyandang disabilitas lebih sering terjadi dari pada terhadap seseorang tanpa kondisi disabilitas. Penyandang disabilitas memiliki resiko besar mengalami kekerasan dari pada seseorang tanpa kondisi disabilitas. Lazimnya, pelecehan seksual terhadap penyandang disabilitas relatif lebih tinggi.

Dalam pemeriksaan, Penyidik mengalami kesulitan berkomunikasi karena korban merupakan penyandang disabilitas rungu dan disabilitas wicara. Pada perkara ini juga tidak ada saksi yang melihat langsung peristiwa pidana tersebut. Hanya diketahui secara langsung oleh korban dan tersangka. Penyidik dalam membuat terang perkara tersebut harus membuktikan unsur daripada Pasal yang disangkakan yaitu Pasal 286 Jo Pasal 285 Jo Pasal 289 KUHP.

Masalah tersebut teratasi ketika adik dari korban membantu komunikasi dengan korban. Pada pemeriksaan penyidikan korban juga di damping oleh guru dari Sekolah Dasar Luar Biasa (SDLB) Lubuk Basung. Pada awalnya korban menunjukan tempat dimana tersangka menyetubuhi korban yaitu bertempat di Rumah Kosong dekat kantor Wali Jorong, di dekat Batang Sawit belakang rumah, namun saksi tidak mengetahui pasti kapan waktu nya tersangka melakukan persetubuhan terhadap korban tersebut karena korban tidak dapat menjelaskannya. Waktu terjadi persetubuhan oleh penyidik kemudian diperkira terjadi berdasarkan pada hasil pemeriksaan ahli forensik yang berbentuk hasil visum et repertum. Korban juga menerangkan bahwa tersangka sering menyetubuhi nya. Cara dilakukannya persetubuhan diterangkan oleh korban dengan cara memperagakan kembali apa yang dilakukan tersangka terhadapnya.

Kesulitan penyidik memeriksa korban lainnya adalah selain tidak dapat mendengar (Tuli), tidak berbicara (bisu), sehingga tidak dapat berkomunikasi layak nya seperti orang normal, dan tidak pernah bersekolah, sehingga pemikirannya seperti anak-anak karena tidak mengetahui apa yang dilakukan tersebut baik atau salah dan korban tersebut tidak mengetahui apa yang telah dialaminya sekarang salah atau benar dan apa akibatnya. Untuk mengatasi ini penyidik menggunakan jasa penerjemah yaitu Guru SDLB Lubuk Basung. Fungsi penerjemah adalah mengartikan Bahasa tubuh yang digunakan korban dalam memberikan keterangan terhadap penyidik. Namun, ternyata mengalami kesulitan karena bahasa isyarat korban dengan penerjemah berbeda, serta jenjang pendidikan korban yang tidak pernah bersekolah. Selanjutnya, penerjemah berinisiatif memanggil adik korban untuk membantu menerjemahkan bahasa isyarat antara korban dengan Penyidik.

Keterbatasan berupa tidak dapat berbicara dan mendengar dengan baik penyidik mengalami kesulitan saat dimintai keterangan. Untuk menjamin hak penyandang disabilitas rungu-wicara terpenuhi sesuai Peraturan Perundang-undangan, mereka wajib didampingi oleh 
penerjemah bahasa isyarat yang memadai. Pada pemeriksaan Tindak pidana cabul dengan korban tuna rungu dan tuna wicara dalam memeriksa korban digunakan alat peraga atau gambar untuk mempermudah korban mengingat peristiwa yang menimpanya, karena ingatan korban sebagai penyandang disabilitas tuna wicara memiliki keterbatasan. Kemudian, selain melakukan rekonstruksi versi pelaku, rekontruksi juga dilakukan berdasarkan versi korban agar mendapat cerita yang lebih utuh.

Bagi aparat penegak hukum yaitu polisi akan mudah membuktikan kebenaran materil bila saksi dapat menunjukan bukti kesalahan yang melakukan tindak pidana dan tersangka mengaku bukti tersebut yang digunakan dalam melakukan tindak pidana. Tetapi hal ini akan sulit untuk membuktikan kebenaran materil, bila saksi tidak dapat menunjukann bukti permulaan tindak pidana yang dilakukan tersangka. Bukti-bukti yang ditemukan ditempat kejadian dan seharusnya saksi dapat menunjukan bahwa bukti tersebut yang digunakan atau milik korban atau saksi yang digunakan oleh tersangka.

Guna melengkapi alat bukti untuk memenuhi unsur daripada suatu tindak pidana maka disamping keterangan saksi korban, penyidik juga menggunakan bantuan ahli psikologi, ahli hukum pidana dan kedokteran kehakiman.

Penyidikan kasus tindak pidana yang tidak didukung dengan alat bukti sah minimal dua alat bukti sah untuk membuktikan bersalah atau tidak bersalah tersangka, maka aparat penegak hukum sulit membuktikaan bersalah atau tidak bersalah tersangka. Eksistensi ilmu kriminalistik di dalam hukum pidana materi sangat memberikan ruang untuk bagaimana ilmu-ilmu bantu yang terdapat di dalam kriminalistik itu diterapkan dan difungsikan untuk bagaimana dapat berusaha dalam upaya penegak hukum atau polisi untuk bisa dapat dengan muda membangun komunikasi sambung nalar ilmu pengetahuan dalam menemukan pelaku tindak pidana. Perempuan disabilitas yang tuna rungu dan tuna wicara di berbagai belahan bumi sering dipandang lebih rendah, hingga pada akhirnya ketika terjadi praktek kekerasan atau pelecehan seksual pada mereka adalah merupakan suatu hal yang wajar dan merupakan kodrat mereka yang kemudian melahirkan sikap pasrah saja.

Untuk itu mengatasi berbagai persoalan tersebut petugas Unit PPA pun mendapatkan bekal pelatihan khusus tentang teknik dan taktik penanganan para korban yang demikian, termasuk juga personil dan ruangan pemeriksaannya pun khusus sehingga tidak menimbulkan trauma yang lebih jauh lagi. Bagaimana menangani perempuan dan menangani anak tidak sama, semuanya memerlukan kiat khusus sehingga pemeriksaan akan berjalan dengan lancar dan akhirnya pelaku dapat dijerat sesuai dengan ketentuan perundang undangan yang berlaku.

\section{Kendala Dalam penggunaan Kriminalistik Dalam Penyidikan Tindak Pidana Cabul Terhadap Korban Tuna Wicara Oleh Unit PPA Satreskrim Polres Agam}

Kendala yang dihadapi terkait dengan proses pendampingan bagi penyandang disabilitas ketika berhadapan dengan hukum atau penyidik, terdapat beberapa kendala dan permasalahan yang ditemui di antaranya adalah belum ada peraturan per-Undang-Undangan yang mengatur tentang hukum dan keadilan yang mempunyai perspektif jender dan disabilitas secara khusus. 
Hal ini membuat tidak adanya SOP/mekanisme penanganan perempuan disabilitas sebagai korban kekerasan seksual.

Kendala kedua adalah pihak penyidik yang memiliki keterbatasan waktu dalam memproses berkas dari tindak pidana tersebut. Dengan keterbatasan waktu yang diberikan untuk mengungkap tindak pidana tersebut, pihak penyidik mengalami kesulitan untuk menyelesaikan berkas perkara seusia target yang di tentukan dari waktu satu bulan. Keterbatasan waktu adalah terkait pada waktu penahan yang dijalani oleh pelaku. Sementara penyidik kesulitan untuk memeriksa korban tindak pidana pencabulan yang tuna rungu dan tuna wicara. Berkas tersebut baru dapat selesai atau terungkap setelah batas waktu penahanan hampir habis. Hal tersebut dikarenakan jumlah atau kuota dari penyidik mengalami kekurangan personel. Saat ini, jumlah personel penyidik yang terdapat di dalam Unit PPA Polres Agam adalah hanya 3 (tiga) orang penyidik yang mengungkap tindak pidana kekerasan seksual pada korban disabilatas tuna wicara dan tunan rungu. Pada kondisi sekarang, satu orang penyidik harus mengungkap sekitar 5-6 Laporan Polisi sehingga penyidik harus bekerja ekstra keras. Jumlah personel tersebut berbanding jauh dengan besar wilayah dari kabupaten Agam dan jumlah penduduknya sehingga dalam pelaksanaan pengungkapan tindak pidana kekerasan seksual pada korban disabilitas masih kurang maksimal. Personel pada unit PPA Polres Agam juga diberi tugas untuk menangani perkara lainnya.

Belum ada kebijakan yang menyediakan saksi ahli, penerjemah, visum kejiwaan, pemeriksaan terkait disabilitas, contoh telinga, hidung dan tenggorokan bagi perempuan atau anak perempuan dengan disabilitas rungu/ wicara korban kekerasan. Hal ini masih merupakan bagian dari teknik dan taktik penyidik dalam melakukan penyidikan tindak pidana cabul dengan korban disabilitas tuna rungu dan tuna wicara. Saksi ahli pada penyidikan ini didatangkan dari kota Padang sehingga membutuhkan waktu yang lama untuk dating ke Polres Agam.

Pada Penyidikan mengenai tindak pidana kekerasan seksual pada tuna wicara dan tuna rungu, salah satu langkah penyidik mendapatkan alat bukti dari adanya tindak pidana kekerasan seksual pada tuna wicara dan tuna rungu adalah dengan melakukan visum. Dalam pelaksanaannya, tidak ditemukan kesulitan yang sangat memberatkan pihak penyidik, akan tetapi sebagian besar korban beserta keluarganya yang melakukan visum adalah berasal dari keluarga yang kurang mampu dalam hal perekonomian. Pihak korban dan keluarganya sering merasa keberatan umtuk membayar proses visum yang cukup mahal. Visum yang dilakukan mengeluarkan biaya rata-rata sekitar Rp. 60.000 hingga Rp. 300.000 dan belum termasuk obatobatan yang diterima. Perbedaan dalam penentuan tarif dalam melakukan visum sangat tergantung dari pengobatan yang dilakukan. Visum dapat dilakukan di Rumah Sakit Kepolisian setelah pembuatan surat pengantar SPKP yang berdasar kepada Laporan Polisi yang dibuat oleh korban dan keluarganya dan pihak SPKP memproses dengan membuat surat permohonan kepada kepala Rumah Sakit untuk melakukan visum kepada korban tindak pidana tersebut. Apabila tidak terdapat surat permohonan dari SPKP maka hasil visum yang dilakukan oleh korban tidak dianggap sah secara hukum sebagai alat bukti. 
Di dalam KUHAP (kitab undang-undang hukum acara pidana) kurang mengenai penjelasan tentang kriminalistik. Penjelasan mengenai kriminalistik harus ditambah di dalam KUHAP sehingga mempermudah aparat penegak hukum khususnya penyidik mengenai penggunaan ilmu kriminalistik. Kurang profesionalismenya cara bekerja aparat penegak hukum dalam mengungkap suatu perkara. Padahal Profesionalisme aparat penegak hukum sangat dibutuhkan agar suatu kasus dapat terungkap dengan cepat. Faktor penegak hukum merupakan "ujung tombaknya" sistem peradilan pidana. Masih banyak penyidik yang tidak memahami ilmu kriminalistik dengan baik. Fungsi ilmu kriminalistik adalah memberikan petunjuk bagi penyidik dalam mencari cara atau menetapkan strategi yang akan digunakan dalam mengungkap suatu tindak pidana. Guna kepentingan ini diperlukan latar belakang pendidikan dan keahlian yang cukup bagi penyidik.

Selanjtnya adalah faktor penegak hukum. Ini tergantung koordinasi antara penegak hukum. Apabila masing-masing anggota aparat penegak hukum kurang profesional maka hal tersebut dapat memperhambat pengungkapan suatu perkara. Kurang tegaknya hukum juga memperhambat penegakan hukum terutama untuk kasus-kasus yang ada kekhususan seperti korbannya adalah tuna wicara atau tuna rungu.

Sarana dan prasarana yang mendukung mencangkup tenaga manusia yang berpendidikan dan terampil, organisasi yang baik, peralatan yang memadai, keuangan yang cukup. Tanpa sarana fasilitas yang memadai, penegakan hukum tidak dapat berjalan dengan lancar dan penegak hukum tidak mungkin menjalankan peranannya sebagaimana mestinya. Teknologi yang dimiliki belum sesuai dengan perkembangan jaman dalam arti lain teknologi yang dimiliki belum canggih. Sarana belum lengkap atau belum memadai. Terutama untuk pemeriksaan alat reproduksi dimana sarana yang ada di rumah sakit belum lengkap. Kurangnya sarana dan prasarana yang memadai untuk penyelidikan dan pengungkapan dari tindak pidana cabul pada korban yang tuna wicara dan tuna rungu di Unit PPA Polres Agam yaitu tempat penyidikan yang sempit, perlengkapan alat-alat kantor yang tidak ditanggung dari pemerintah seperti peralatan komputer, rak lemari untuk menyimpan berkas-berkas serta meja dan kursi sehingga penyidik melakukan swadaya sendiri, adanya penggunaan ruang penyidikan yang kurang maksimal, terbatasnya dana atau biaya untuk menyelidiki sebuah tindak pidana. Kondisi ruangan yang tidak memadai terkadang membuat korban bertambah trauma dalam pemeriksaan terhadapnya, apalagi korban mengalami keterbelakangan berpikir karena tidak mengecam pendidikan.

\section{PENUTUP}

Pihak pemerintah sebaiknya dapat membantu secara finansial kepada korban dan keluarganya dari tindak pidana kekerasan seksual pada korban tuna wicara yang berasal dari kurang mampu atau dapat memberikan subsidi untuk pembiayaan dari prosess visum sehingga tidak memberatkan dari pihak korban dan keluarganya. Pihak penyidik dapat membuat kerjasama dalam mekanisme penanganan korban tuna wicara yang menjadi korban tindak pidana kekerasan seksual dengan membuka pelayanan khusus. 


\section{DAFTAR PUSTAKA}

Ahmad Saleh, Hukum Tata Negara, Indepth Publishing, Bandar lampung, 2014.

Chainur Arrasjid, Dasar-Dasar Ilmu Hukum, Sinar Grafika, Jakarta, 2000

Mahrus Ali, Dasar-Dasar Hukum Pidana, Sinar Grafika, Jakarta, 2001

Djisman Samosir, Segenggam Tentang Hukum Acara Pidana, Nuansa Aulia, Bandung, 2013

Reiter, Shunit, Diane N. Bryen, and Ifat Shachar, Adolescents with Intellectual Disabilities as Victims of Abuse." Journal of Intellectual Disabilities Vol 11(4), 2007 